\title{
Prognostic values of physical and hematological parameters of dogs naturally infected with parvovirus PVC-2: retrospective study of 103 cases

[Valores prognósticos de parâmetros físicos e hematológicos de cães naturalmente infectados pelo parvovírus $P V C$-2: estudo retrospectivo de 103 casos]

\author{
F.S. Alves ${ }^{1}$, F.H. Alonso ${ }^{2}$, R.S. Horta ${ }^{3}$, B.C. Barbosa ${ }^{1}$, S. Beier ${ }^{4}$, P.R.O. Paes ${ }^{4}$ \\ ${ }^{1}$ Aluno de pós-graduação - Universidade Federal de Minas Gerais - Belo Horizonte, MG \\ ${ }^{2}$ Aluno de pós-graduação - University of California - Davis, U.S.A. \\ ${ }^{3}$ Universidade de Vila Velha - Vila Velha, ES \\ ${ }^{4}$ Universidade Federal de Minas Gerais - Belo Horizonte, MG
}

\begin{abstract}
Canine parvovirosis is a high mortality disease with acute clinical picture. However, there are few available resources to help stablish prognosis accurately. This study aimed to determine the prognostic threshold values for vital and hematological parameters of dogs naturally infected by the Carnivore protoparvovirus 1 (CPV). A retrospective study of 103 canine parvovirosis cases was carried out. Twenty seven percent of these (28/103) died, 96\% (27/28) of which within the first four days of hospitalization. Deceased animals had significantly higher median values for heart (HR) and respiratory (f) rates, as well as significantly lower systolic blood pressure (SBP) than survivors. Severely leukopenic animals $(<1,000$ cells $/ \mu \mathrm{L})$, had a significantly higher mortality rate $(68 \%, \mathrm{n}=13)$ compared to that of other patients $(\mathrm{P}<0.0007)$. Animals with at least two of the following findings: severe hypotension ( $\mathrm{SBP}<90 \mathrm{mmHg})$, tachycardia $(\mathrm{HR}>150 \mathrm{bpm})$ and leukopenia, represented 34\% (34/101) of the cases and had a survival rate of $29 \%(10 / 34)$, while animals with at most one of these parameters represented $66 \%(67 / 101)$ and had a survival rate of $94 \%$ $(63 / 67)$. The presence of two or three abnormal parameters was significantly related to the higher death risk among dogs with parvovirosis $(\mathrm{P}<0.0001)$.
\end{abstract}

Keywords: hypotension, leukopenia, mortality, parvovirosis, tachycardia

\section{RESUMO}

A parvovirose canina é uma doença de alta mortalidade e de quadro clínico agudo. No entanto, existem poucos recursos para se estabelecer prognóstico de maneira precisa. Este estudo objetivou analisar os valores prognósticos de parâmetros físicos e hematológicos de cães naturalmente infectados pelo Carnivore protoparvovirus 1 (CPV). Um estudo retrospectivo de 103 casos de parvovirose canina foi realizado. Desses, 27\% dos animais (28/103) foram a óbito, sendo 96\% (27/28) com ocorrência nos primeiros quatro dias de internamento. Os cães que foram a óbito apresentaram medianas das frequências cardíaca $(F C)$ e respiratória (f) significativamente maiores e pressão arterial sistólica (PAS) consideravelmente menor que a dos sobreviventes. Entre os animais mais intensamente leucopênicos $(<1.000$ células $/ \mu L)$, a taxa de mortalidade $(68 \%, n=13)$ foi expressivamente maior que a dos demais pacientes $(P<0,0007)$. Os animais com hipotensão grave $(P A S<90 \mathrm{mmHg})$, taquicardia $(F C>150 b p m) e$ leucopenia intensa (leucometria $<1.000$ células $/ \mu L$ ), ou duas dessas alterações clínicas, representaram $34 \%$ (34/101) dos casos e tiveram taxa de sobrevida de 29\% (10/34), enquanto os animais com, no máximo, um desses parâmetros alterados representaram 66\% (67/101) dos animais, com taxa de sobrevida de $94 \%$ (63/67). A presença de dois ou três parâmetros alterados esteve significativamente relacionada ao maior risco de óbito de cães com parvovirose $(P<0,0001)$.

Palavras-chave: hipotensão, leucopenia, mortalidade, parvovirose, taquicardia

Recebido em 29 de maio de 2019

Aceito em 28 de agosto de 2020

E-mail: fsalves.vet@gmail.com 


\section{INTRODUCTION}

Canine parvovirosis was first reported in 1973 and still represents a disease with high mortality rate in young dogs (Goddard and Leisewitz, 2010). Clinical signs can be acute and severe, forcing intensive care professionals to take immediate decisions regarding diagnosis and implementation of supportive therapy. Canine parvovirus (CPV) is a member of the Protoparvovirus genus (family Parvoviridae, subfamily Parvovirinae) responsible for canine parvovirosis. (Cotmore et al., 2019). One to three days after exposure to contaminated feces, viral replication begins in the lymphoid tissue of the oropharynx, mesenteric lymph nodes and thymus, which may result in lymphoid cell depletion.

Concurrently to this, destruction of hematopoietic cell precursors in the bone marrow and induction of a cellular immune response may occur, leading to severe hematological abnormalities, manifested mainly in neutrophil and lymphocyte blood counts (Parrish, 1995; Schoeman et al., 2013). Lymphoid tissue depletion and destruction of bone marrow precursors, aggravated by increased cellular demand, can trigger leukopenia, which is correlated with a higher risk of death (Rosenfeld and Young, 1991; Goddard et al., 2008; Schoeman et al., 2013).

The most found risk factor in this disease is the lack of protective immunity, either by unsuccessful transferring of passive immunity or by incomplete/absent vaccination schedule. Vaccine-induced immunity failure may also happen due to interference from maternal antibodies, which have a half-life of approximately 10 days (Smith-Carr et al., 1997; Truyen and Horzinek, 2007; Siedek et al., 2011; Day et al., 2016). With so many different tissues getting injured, by such pathogenic variety, there are still few tools to help stablish or gauge data such as patient's survival time or chance of recovery. The objective of this study was to verify the prognostic value of clinical parameters and hematologic abnormalities at admission time and throughout the hospitalization of dogs naturally infected with canine parvovirosis.

\section{MATERIALS AND METHODS}

A retrospective study of canine parvovirosis cases consulted at the Veterinary Hospital of the Federal
University of Minas Gerais (UFMG), Brazil, from January 2014 to July 2017, was carried out through access to medical records database. Patients with less than 12 months old, with diagnosis of parvovirosis confirmed by means of the chromatographic immunoassay technique (BioEasy ${ }^{\circledR}$ - AlereParvovirose, Ag Bionote Inc., Korea) from a fecal swab sample, were included, totalizing 103 cases. Medical records were examined for age, number of days till death, heart rate $(\mathrm{HR})$, respiratory rate (f), systolic blood pressure (SBP) and rectal temperature (Tr) at admission.

The following reference intervals/cut-offs were used for clinical parameters of puppies: HR between 70 and $150 \mathrm{bpm}$, f of up to 40 breaths per minute, $\operatorname{Tr}$ between $37.5^{\circ} \mathrm{C}$ and $39.2^{\circ} \mathrm{C}$, and finally, the minimal SBP of $120 \mathrm{mmHg}$ and maximum of $150 \mathrm{mmHg}$. Patients with $\mathrm{SBP} \leq$ $90 \mathrm{mmHg}$ were classified as severe hypotension (Brown et al., 2007; Acierno et al., 2018). From the 103 cases analyzed, three were from the age group of zero to two months of age, 37 had two to four months of age, 29 had five to six months of age and 34 had seven to 12 months of age.

From the 103 cases analyzed, $101(98.1 \%)$ had available complete blood count (CBC) from the day of admission to the veterinary hospital (M1). In addition, 29 cases $(28.2 \%)$ had three serial CBC's, performed at M1, between the second or third day of hospitalization (M2-3) and between the fourth or fifth day of hospitalization (M4-5). Blood samples were collected in tubes containing ethylenediaminetetraacetic acid (EDTA) and processed within a maximum of 12 hours. Packed cell volume (PCV) was obtained by centrifugation. Erythrocyte, total leukocytes and platelet counts (PLT), along with hemoglobin concentrations were obtained using an automated hematological counter device. Erythrocytic indices (mean corpuscular volume [MCV], mean corpuscular hemoglobin $[\mathrm{MCH}]$ and mean corpuscular hemoglobin concentration [MCHC]) were obtained by means of calculation. Leukocyte differential count were performed on 100 cells and the morphological evaluations done in blood smears made within a maximum of one hour after blood collection.

A completely randomized design was used. Plots were formed by two groups, defined by prognosis (survival or death) and each animal represented an 
experimental unit or repetition. The Prism 6.02 software (GraphPad, San Diego, CA, USA) was used and the differences were considered significant with $\mathrm{P}<0.05$. Frequency of deaths among the 101 cases was compared by the chisquare test. Considered criteria included time (less than or greater than four days), total leukocyte count (TLC, < 1000, 1000-1499, 1500-1999, 2000-2999, 3000-5999 and > 6000) and number of abnormal parameters (physical and hematological). Spearmann's correlation was used to verify the relation between the prognosis and the other variables studied (age, vital parameters and $\mathrm{CBC}$ data) among the 101 cases.

Significant correlations were considered strong when they occurred in more than $49 \%$ of the studied population $\left(\mathrm{r}_{\mathrm{S}}>0.7\right)$, moderate, when they occurred in 9 to $49 \%\left(0.3<\mathrm{r}_{\mathrm{s}}<0.7\right)$, and weak when they occurred in less than $9 \%$ of the population $\left(\mathrm{r}_{\mathrm{S}}<0.3\right)$. The parametric clinical (age, vital parameters) and hematological variables were tested for normality by the KolmogorovSmirnov test. Comparison of means (for parametric distribution) and medians (for nonparametric distribution) in the 101 cases among surviving and deceased patients were performed by the Mann-Whitney test (HR, f, Tr, SBP, TLC and PLT) and t-student (PCV). When considering the degree of leukopenia, patients were divided into six groups $(<1000,1000-1499$, 1500-1999, 2000-2999, 3000-5999 and > 6000), and the comparison was performed by the Kruskal-wallis ad-hoc Dunns (age, platelets, neutrophils and lymphocytes counts) and ANOVA ad-hoc Tukey (PCV).

Considering the three moments of hematological evaluation (M1- admission, M2- second or third day of hospitalization, M3- fourth or fifth day of hospitalization), the Kruskal-wallis ad-hoc Dunns (TLC) and ANOVA ad-hocTukey (PCV and PLT) tests were used.

\section{RESULTS AND DISCUSSION}

In the present study, a mortality rate of $27.2 \%$ (28/103) was observed, attributed to complications from canine parvovirosis. This rate is similar to that reported in previous studies (Prittie, 2004; Gombač et al., 2008; Ntafis et al., 2010; Pintos et al., 2011; Brady et al., 2012; Castro et al., 2013). Deaths were mainly concentrated in the first four days of hospitalization. Twenty five percent $(7 / 28)$ on the first day; $35.7 \%(10 / 28)$ on the second; $28.6 \%$ $(8 / 28)$ on the third and $7.1 \%(2 / 28)$ on the fourth day of hospitalization. The first four days represented, therefore, the hospitalization time frame for $96.4 \%(27 / 28)$ of deceased animals. Eighty nine percent $(25 / 28)$ of deaths occurred in the first three days. Only one case occurred outside the four-day period, more precisely on the eleventh day of hospitalization. Mortality rate was therefore $24.8 \%(27 / 103)$ on the first four days and $1.3 \%(1 / 76)$ on subsequent days. This difference was highly significant $(\mathrm{P}<0.0001)$ by the chi-square test.

The mean age of animals diagnosed with canine parvovirosis was $5.7 \pm 0.7$ months, with $2 / 3$ of cases $(66.7 \%)$ concentrating within three to six months. This result agrees with Prittie (2004), who reports greater parvovirosis morbidity in dogs up to six months of age. Oliveira et al. (2019) and Filipov et al. (2011) also reported similar ranges for affected dogs. This age group accounted for $42.8 \%(12 / 28)$ of deaths in this study and, according to the Spearmann correlation analysis and the Mann-Whitney test, there was no association with death occurrence.

Most animals affected by canine parvovirosis had not been vaccinated $(46.6 \%, \mathrm{n}=48)$ or had an incomplete vaccination schedule $(30.0 \%, \mathrm{n}=31)$. Among the other dogs, $4.9 \%(n=5)$ had complete vaccination and in $18.4 \%(n=19)$ there was no information about vaccination status. Among the $31 \mathrm{dog}$ with incomplete vaccination schedule, 12 dogs belonged to the age group of 2 to 4 months, ten to the age group of 5 to 6 months and nine to the age group of 7 to 12 months. These data are similar to those reported by Ling et al. (2012) for Australian dogs with parvovirosis. As for death occurrence, there was no correlation between vaccination status and prognosis $(\mathrm{P}=0.4)$ and no difference in mortality compared to vaccination status, using the chi-square test $(\mathrm{P}=0.4)$. The main factors that may be associated with the percentage of vaccinated dogs that became ill ( $4.9 \%$ of cases) include interference from maternal antibodies, variant strains and excessive viral loads (Gese et al., 1991; Schunck and Truyen, 1995; Van Heerden et al., 2002; Decaro et al., 2005; Lamm and Rezabek, 2008; Jin et al., 2012). 
Table 1. Clinical (physical parameters) and main hematological parameters obtained at the time of admission at Veterinary Teaching Hospital in survivors $(n=75)$ and non survivors $(n=28)$ dogs with canine parvovirus infections

\begin{tabular}{|c|c|c|c|c|c|c|c|}
\hline & \multicolumn{4}{|c|}{ Physical parameters } & \multicolumn{3}{|c|}{ Hematological } \\
\hline & $\begin{array}{c}\mathrm{HR} \\
(\mathrm{bpm})\end{array}$ & $\begin{array}{c}\mathrm{f} \\
(\mathrm{Bpm})\end{array}$ & $\begin{array}{c}\mathrm{Tr} \\
\left({ }^{\circ} \mathrm{C}\right) \\
\end{array}$ & $\begin{array}{c}\text { SBP } \\
(\mathrm{mmHg})\end{array}$ & $\begin{array}{c}\text { PVC } \\
(\%)\end{array}$ & $\begin{array}{c}\text { TLC } \\
\text { (cells } / \mu \mathrm{L})\end{array}$ & $\begin{array}{c}\text { PTL } \\
\left(\times 10^{3} / / \mu \mathrm{L}\right)\end{array}$ \\
\hline $\begin{array}{l}\begin{array}{l}\text { Survivors } \\
(\mathrm{n}=75)\end{array} \\
\text { Mean } \pm \mathrm{SD} \\
{[\text { Median] }}\end{array}$ & $148 \pm 25.5 \mathrm{a}$ & $28 \pm 15.6 \mathrm{a}$ & $38.5 \pm 0.9 \mathrm{a}$ & $96 \pm 8.5 \mathrm{a}$ & $38.4 \pm 7.6 \mathrm{a}$ & $\begin{array}{c}4.133 \pm 5.385 \\
{[2.470 \mathrm{a}]}\end{array}$ & $\begin{array}{c}286.8 \pm 164.7 \\
{[265.0 \mathrm{a}]}\end{array}$ \\
\hline $\begin{array}{l}\text { Non survivors } \\
(\mathrm{n}=28) \\
\text { Mean } \pm \mathrm{SD} \\
{[\text { Median] }}\end{array}$ & $172 \pm 15.6 \mathrm{~b}$ & $45 \pm 5.7 \mathrm{~b}$ & $38.8 \pm 0.1 \mathrm{a}$ & $85 \pm 1.4 \mathrm{~b}$ & $38.2 \pm 9.2 \mathrm{a}$ & $\begin{array}{c}1.934 \pm 2.136 \\
{[1.030 \mathrm{~b}]}\end{array}$ & $\begin{array}{c}231.6 \pm 161.4 \\
{[211.7 \mathrm{a}]}\end{array}$ \\
\hline Statistics & $\begin{array}{c}\text { Mann- } \\
\text { Whitney } \\
(\mathrm{P}=0.005)\end{array}$ & $\begin{array}{c}\text { Mann- } \\
\text { Whitney } \\
(\mathrm{P}=0.0006)\end{array}$ & $\begin{array}{c}\text { Mann- } \\
\text { Whitney } \\
(\mathrm{P}=0.8)\end{array}$ & $\begin{array}{c}\text { Mann- } \\
\text { Whitney } \\
(\mathrm{P}<0.0001)\end{array}$ & $\begin{array}{l}\text { t-student } \\
(\mathrm{P}=0.9)\end{array}$ & $\begin{array}{c}\text { Mann-Whitney } \\
(\mathrm{P}=<0.0001)\end{array}$ & $\begin{array}{l}\text { Mann-Whitney } \\
\quad(\mathrm{pP}=0.1)\end{array}$ \\
\hline
\end{tabular}

HR: Heart rate; f: Respiratory rate; Tr: Rectal temperature; SBP: Systolic blood pressure; bpm: Beats per minute; Bpm: Breaths per minute; PVC: packed cell volume; TLC: total leukocyte count; PTL: platelets; SD Standard deviation. Different lowercase letters refer to distinct medians by statistical test.

Deceased animals had significantly higher median values for $H R$ and $f$ and significantly lower median value for SBP compared to those who survived. There was no significant difference in Tr between the two groups. The Spearmann test revealed a positive correlation between death and the variables $\mathrm{HR}$ (weak, $\mathrm{P}=0.005, \mathrm{r}_{\mathrm{S}}=0.277$ ) and $\mathrm{f}$ (moderate, $\mathrm{P}=0.0005, \mathrm{r}_{\mathrm{S}}=0.366$ ), and a negative correlation between death and SBP (moderate, $\left.\mathrm{P}<0.0001, \quad \mathrm{r}_{\mathrm{S}}=-0.442\right)$. These associations between clinical variables and prognosis were not observed by Kalli et al. (2010). The authors were able to observe that animals that met the criteria of systemic inflammatory response syndrome (SIRS) had greater severity, though.

Tachycardia was observed in $85.7 \%(24 / 28)$ of cases of death (moderate correlation, $\mathrm{P}=0.0005$ ) and $44.0 \%(33 / 75)$ of survival cases. Tachypnea, present in $53.6 \%(15 / 28)$ of deceased dogs and in $25.3 \%(19 / 75)$ of those who survived, had a weak correlation with death $(\mathrm{P}=0.03)$. In relation to SBP, $89.2 \%$ (25/28) of deceased dogs had values consistent with severe hypotension (moderate correlation, $\mathrm{P}<0.0001)$. The same condition was observed in $28.0 \%(21 / 75)$ of survivors. In relation to $\mathrm{Tr}$, there was no correlation $(\mathrm{P}=0.09)$ between the parameter and survival or death outcomes. Individuals from both groups presented predominantly in normothermia.

Tachycardia and hypotension may be attributed to decreased tissue perfusion generated by dehydration, secondary to gastrointestinal loss of fluid and proteins (Prittie, 2004; Schoeman et al., 2013; Rolim et al., 2014). Tachypnea may be a consequence of the response to abdominal pain, frequent in dogs with parvovirosis, or a compensatory response to a possible metabolic acidosis (Prittie, 2004; Goddard and Leisewitz, 2010; Mylonakis et al., 2016).

CBC results from all animals at $\mathrm{M} 1$ revealed mean PCV of $38.3 \%$ (RI: $37-55 \%$ ), TLC of 3,523 cells/ $\mu \mathrm{L}$ (RI: $6.000-17.000$ cells $/ \mu \mathrm{L}$ ), PLT of 272,000 cells/ $\mu \mathrm{L}$ (RI: $175,000-500,000$ cells $/ \mu \mathrm{L}$ ). Although mean PCV was within RI, $48.5 \%$ of dogs in the study presented anemia at M1. Thrombocytopenia was present in $24.8 \%$ of CBC's and leukopenia was observed in $85.1 \%$ of cases, mainly due to neutropenia and lymphopenia, which were observed in $97.5 \%$ and $88.9 \%$ of CBC's, respectively. Results of CBC's at M1, according to life status (death or survival), are shown in Table 1.

According to Table 1, there was no statistically significant difference between PCV from survival and death groups with both means near the lower reference cutoff for the species. There was also no significant difference between groups for PLT. In relation to TLC, however, deceased dogs had significantly lower values $(\mathrm{P}<0.0001)$ than survivors. In this study, mean TLC $(4,133$ cells $/ \mu \mathrm{L}$ ) in survival group was lower than those observed by Castro et al. (2013) and Goddard et al., (2008), while severe leukopenia, among deceased dogs, was a common finding in all three studies. Neutropenia is one of the most common hematologic abnormality in dogs diagnosed with parvovirosis (Macartney et al., 1984). 
It is attributed to the destruction of hematopoietic precursors of granulocytic lineage in the bone marrow, as well as lymphoid precursors in other lymphoproliferative organs such as thymus, lymph nodes, and spleen (Boosinger et al., 1982; Meunier et al., 1985; Parrish, 1995; Breuer et al., 1998; Dossin et al., 2011).

Table 2. Number of animals, percentage of deaths, mean values and standard deviations (SD) for PCV and median values for platelets count (PLT) and age of 101 dogs naturally infected by CPV, according to total leukocyte count (TLC) interval, performed at admission moment

\begin{tabular}{lccccccc}
\hline $\begin{array}{c}\text { TLC } \\
(\text { cells } / \mu \mathrm{L})\end{array}$ & $\begin{array}{c}\text { Animals } \\
(\mathrm{n})\end{array}$ & $\begin{array}{c}\text { Deaths } \\
(\mathrm{n})\end{array}$ & $\begin{array}{c}\text { \% of } \\
\text { deaths in } \\
\text { the group }\end{array}$ & $\begin{array}{c}\text { \% of deaths } \\
\text { in total of } \\
\text { deaths }\end{array}$ & $\begin{array}{c}\text { Age } \\
\text { (months })\end{array}$ & $\begin{array}{c}\text { PCV } \\
(\%)\end{array}$ & $\begin{array}{c}\text { PLT } \\
\left(\mathrm{x} 10^{3}\right. \\
\text { cells } / \mu \mathrm{L})\end{array}$ \\
\hline$<1,000$ & 19 & $13 \mathrm{a}$ & 68.4 & 46.4 & $5.0 \mathrm{a}$ & $38.6 \pm 7.5 \mathrm{a}$ & $240.0 \mathrm{a}$ \\
$1,000-1,499$ & 17 & $5 \mathrm{~b}$ & 29.4 & 17.9 & $4.0 \mathrm{a}$ & $37.8 \pm 8.4 \mathrm{a}$ & $319.0 \mathrm{a}$ \\
$1,500-1,999$ & 16 & $3 \mathrm{~b}$ & 18.8 & 10.7 & $5.0 \mathrm{a}$ & $38.6 \pm 6.7 \mathrm{a}$ & $279.5 \mathrm{a}$ \\
$2,000-2,999$ & 16 & $2 \mathrm{~b}$ & 12.5 & 7.1 & $5.5 \mathrm{a}$ & $39.3 \pm 9.4 \mathrm{a}$ & $282.5 \mathrm{a}$ \\
$3,000-5,999$ & 18 & $3 \mathrm{~b}$ & 16.7 & 10.7 & $6.0 \mathrm{a}$ & $41.3 \pm 8.2 \mathrm{a}$ & $210.0 \mathrm{a}$ \\
$\geq 6,000$ & 15 & $2 \mathrm{~b}$ & 13.3 & 7.1 & $6.0 \mathrm{a}$ & $33.8 \pm 6.2 \mathrm{a}$ & $268.0 \mathrm{a}$ \\
Statistics & - & I & - & - & II & III & IV \\
\hline
\end{tabular}

I: Chi-square ( $\mathrm{P}<0.0007)$; II: Kruskal-Wallis ad-hoc Dunns ( $\mathrm{P}=0.4)$; III: ANOVA ad-hoc Tukey $(\mathrm{P}=0.08)$; IV: KruskalWallis ad-hoc Dunns $(\mathrm{P}=0.1)$.

The non-leukopenic group $(\geq 6,000$ cells $/ \mu \mathrm{L})$ represented $14.9 \%(15 / 101)$ of total cases with CBC (Table 2). Mortality rate in this group was $13.3 \%$ (2/15). Groups containing cases with marked leukopenia $(<2,000$ cells $/ \mu \mathrm{L})$ represented $51.5 \%(52 / 101)$ of patients and had a $40.4 \%$ mortality rate (21/52). Mortality rate was significantly higher among patients with the lowest TLC $(<1,000$ cells $/ \mu \mathrm{L})$, according to the chi-square test $(\mathrm{P}<0.0007)$.

Abnormal TLC values were not accompanied by abnormalities in erythrogram and thrombogram. These findings can be associated with differences in half-life of each cell type. In dogs, neutrophils usually circulate for a few hours, platelets for 710 days and erythrocytes for approximately four months (Stockham and Scott, 2008; Weiser, 2012). Thus, in a situation of decreased/ insufficient bone marrow production secondary to multiple lineage hypoplasia, a low TLC may develop more prematurely(Stockham and Scott, 2008; Weiser, 2012). Table 3 shows the results of serial CBC's performed at M1 and at the next four days, divided into two groups according to TLC from M1.
At M1, mean PCV from both groups was close to the lower range of normality and was below the minimum normal value in the next two moments, characterizing anemia. Mean PCVs from M2-3 and M4-5 were significantly different $(\mathrm{P}<0.0001)$ from M1 in the group TLC $<2,000$ cells $/ \mu \mathrm{L}$. Mean PCV from M4-5 group was also significantly different from M1. These differences may be attributed to decreased production or represent a consequence of hemodilution effect caused by fluid therapy during hospitalization (Bastan et al., 2012; Schoeman et al., 2013).

As expected, mean TLC was significantly different $(\mathrm{P}<0.0001)$ at $\mathrm{M} 1$ between groups (Table 3). However, an increasing tendency in TLC in the group with less than 2,000 leukocytes $/ \mu \mathrm{L}$ was noted in the next moment (M2-3) with concurrent decreasing tendency in the same variable for the group with more than 2,000 leukocytes/ $\mu \mathrm{L}$, which resulted in no significant difference between groups. The absence of statistical difference between groups was maintained in M4-5, with both groups showing an elevation in TLC $(\mathrm{P}<0.0001)$. 
Table 3. Mean and standard deviation (SD) values for PCV and platelet count (PLT) and median value for total leukocyte count (TLC) in blood from dogs naturally infected with CPV obtained at admission (M1), second or third day of hospitalization (M2 -3) and fourth or fifth day of hospitalization (M4-5), according to the TLC interval from M1

\begin{tabular}{|c|c|c|c|c|c|c|}
\hline \multirow[b]{2}{*}{ Parameter } & \multirow{2}{*}{$\begin{array}{c}\text { TLC on } \\
\text { M1 } \\
\text { (céls } / \mu \mathrm{L})\end{array}$} & \multirow{2}{*}{$\begin{array}{l}\text { Cases } \\
\text { (n) }\end{array}$} & \multicolumn{3}{|c|}{ Moment } & \multirow[b]{2}{*}{ Statistics } \\
\hline & & & M1 & M2-3 & M4-5 & \\
\hline \multirow{3}{*}{ PCV (\%) } & $<2,000$ & 15 & $38.9 \pm 8.2 \mathrm{Aa}$ & $27.6 \pm 5.7 \mathrm{Ab}$ & $28.1 \pm 7.2 \mathrm{Ab}$ & ANOVA ad-hoc \\
\hline & $>2,000$ & 14 & $38.3 \pm 9.4 \mathrm{Aa}$ & $32.7 \pm 5.5 \mathrm{Aa}$ & $28.5 \pm 6.1 \mathrm{Ab}$ & Tukey \\
\hline & All & 29 & $38.6 \pm 4.2$ & $30.1 \pm 0$ & $28.3 \pm 2.8$ & $(\mathrm{P}<0.0001)$ \\
\hline \multirow{3}{*}{ TLC (cells/ $\mu \mathrm{L})$} & $<2,000$ & 15 & $1.270 \mathrm{Aa}$ & $3.480 \mathrm{Aab}$ & $5.865 \mathrm{Ab}$ & Kruskal-Wallis \\
\hline & $>2,000$ & 14 & $3.105 \mathrm{Bab}$ & $2.520 \mathrm{Aa}$ & $9.105 \mathrm{Ab}$ & ad-hoc Dunns \\
\hline & All & 29 & 1.960 & 2.570 & 8.190 & $(\mathrm{P}<0.0001)$ \\
\hline \multirow{3}{*}{$\begin{array}{l}\text { PLT } \\
\left(\text { cells } \times 10^{3} / \mu \mathrm{L}\right)\end{array}$} & $<2,000$ & 15 & $311.1 \pm 155.5 \mathrm{Aa}$ & $161.0 \pm 126.5 \mathrm{Ab}$ & $252.2 \pm 173.4 \mathrm{Aab}$ & ANOVA ad-hoc \\
\hline & $>2,000$ & 14 & $215.5 \pm 78.3 \mathrm{Aa}$ & $181.3 \pm 119.1 \mathrm{Aa}$ & $195.5 \pm 139.2 \mathrm{Aa}$ & Tukey \\
\hline & All & 29 & $264.9 \pm 883.8$ & $170.8 \pm 155.6$ & $223.4 \pm 247.5$ & $(\mathrm{P}<0.03)$ \\
\hline
\end{tabular}

Different capital letters in the same column indicates significant differences between groups; different lowercase letters in the same row indicates significant differences between the evaluation moments.

Mortality by canine parvovirosis occurred mainly in the first three days of hospitalization $(89.3 \%$ of cases) and in patients with severe leukopenia (75.0\% of cases). Unlike the latter group, which showed a continuous and progressive increase in TLC, CBC of patients with more than 2,000 leukocytes $/ \mu \mathrm{L}$ had a reduction in TLC during the first two days of hospitalization and an increase in the following two. This finding suggests that dogs of the second group may have been referred to the veterinary hospital at an earlier stage of the disease. Bone marrow changes of these patients would still be in progress and they would have a greater chance of survival due to early institution of supportive therapy.

Microscopic morphological assessment of leukocytes was performed in all CBC`s. Reactive lymphocytes were significantly represented in $32.5 \%$ of CBC's from M1, $25.0 \%$ of M2-3 and $30.4 \%$ of M4-5. Neutrophilic toxic change was present in $13.3 \%, 22.2 \%$ and $34.8 \%$ of CBC's from M1, M2-3 and M4-5, respectively. Because the mean neutrophil count and the number of CBC's with reported toxic change increased concurrently in each different evaluated moment, it can be inferred that the increase in number of toxic neutrophils was absolute and not just relative. According to Stockham and Scott (2008), toxic neutrophils are found in circulating blood because of defects in cell maturation when there is acceleration of neutropoiesis.

This finding is mainly associated with severe inflammatory process and infectious or necrotic processes. Reactive lymphocytes, on the other hand, are observed in a wide variety of inflammatory diseases, being more common in chronic inflammatory conditions, or those associated with a strong antigenic stimulation (Stockham and Scott, 2008). The morphological abnormalities observed in this study are, therefore, most likely a consequence of viral antigenic stimulation and secondary bacterial infection. There was no significant difference at M1 for the variable PLT between groups with more and less than 2,000 leukocytes $/ \mu \mathrm{L}$. Both groups had mean PLT within the reference range (Table 3$)$. The significant decrease $(\mathrm{P}<0.03)$ in PLT for the severely leukopenic group in M2-3 can be attributed to decreased bone marrow production and/or increased consumption/ destruction (Wilson and Hermann-Dekkers, 1982).

The number of abnormal parameters had influence on the survival rate of the animals, $66.3 \%(67 / 101)$ of all animals exhibited either only one or none abnormal parameters and had a survival rate of $94.0 \%$. Patients with two or three abnormal parameters $(33.7 \%$ or $34 / 101)$ had a survival rate of $29.4 \%$. The presence of two or three abnormal parameters was significantly associated with a higher death risk of dogs with CPV $(\mathrm{P}<0.0001)$.

\section{CONCLUSIONS}

The association of physical and hematological findings is very useful as a prognostic factor for dogs with parvovirosis. Patients with severe hypotension, tachycardia and leukopenia, or at least two of these conditions, have significantly higher risk of death. 


\section{REFERENCES}

ACIERNO, M.J.; BROWN, S.; COLEMAN, A.E. et al. ACVIM consensus statement: Guidelines for the identification, evaluation, and management of systemic hypertension in dogs and cats. J. Vet. Intern. Med., v.32, p.1803-1822, 2018.

BASTAN, I.; KURTDEDE, A.; ÖZEN, D. Prognostic usefulness of some parameters in dogs with canine parvovirus. Ank. Univ. Vet. Fak. Dergisi, v.60, p.53-58, 2012.

BOOSINGER, T.R.; REBAR, A.H.; DENICOLA, D.B. et al. Bone marrow alterations associated with canine parvoviral enteritis. Vet. Pathol., v.19, p.558-561, 1982.

BRADY, S.; NORRIS, J.M.; KELMAN, M. et al. Canine parvovirus in Australia: the role of socioeconomic factors in disease clusters. Vet. J., v.193, p.522-528, 2012.

BREUER, W.; STAHR, K.; MAJZOUB, M. et al. Bone-marrow changes in infectious diseases and lymphohaemotopoietic neoplasias in dogs and cats - a retrospective study. J. Comp. Path., v.119, p.57-66, 1998.

BROWN, S.; ATKINS, C.; BAGLEY, R. et al. Guidelines for the identification, evaluation, and management of systemic hypertension in dogs and cats. J. Vet. Intern. Med., v.21, p.542-558, 2007.

CASTRO, T.X.; DE CUBEL GARCIA, R.C.N.; GONÇALVES, L.R.S. et al. Clinical, hematological, and biochemical findings in puppies with coronavirus and parvovirus enteritis. Can. Vet. J., v.54, p.885-888, 2013.

COTMORE, S.F.; AGBANDJE-MCKENNA, M.; CANUTI, M. et al. ICTV Virus taxonomy profile : parvoviridae. J. Gener. Virol., v.100, p.367-368, 2019.

DAY, M.; HORZINEK, M.; SCHULTZ, R. et al. Guidelines for the vaccination of dogs and cats compiled by the Vaccination Guidelines Group (VGG) of the World Small Animal Veterinary Association (WSAVA). J. Small Anim. Pract., v.57, p.1-45, 2016.

DECARO, N.; CAMPOLO, M.; DESARIO, C. et al. Maternally-derived antibodies in pups and protection from canine parvovirus infection. Biologicals, v.33, p.261-267, 2005.
DOSSIN, O.; RUPASSARA, S.; WEN, H. et al. Effect of parvoviral enteritis on plasma citrulline concentration in dogs. J. Vet. Int. Med., v.25, p.215-221, 2011.

FILIPOV, C.; DECARO, N.; DESARIO, C. et al. Canine parvovirus epidemiology in Bulgaria. $J$. Vet. Diagn. Invest., v.23, p.152-154, 2011.

GESE, E.M.; SCHULTZ, R.D.; RONGSTAD, O.J. et al. Prevalence of antibodies against Canine Parvovirus and Canine Distemper Virus in wild coyotes in Southeastern Colorado. J Wildlife Diseases, v.27, n.2, p.320-323, 1991.

GODDARD, A. LEISEWITZ, A.L.; CHRISTOPHER, M. et al. Prognostic usefulness of blood leukocyte changes in canine parvoviral enteritis. $J$ Vet Int Med, v.22, p.309-316, 2008.

GODDARD, A.; LEISEWITZ, A.L. Canine parvovirus. Vet. Clin. N. Am. Small Anim. Pract., v.40, p.1041-1053, 2010.

GOMBAČ, M.; ŠVARA, T.; TADIĆ, M. et al. Retrospective study of canine parvovirosis in Slovenia. Slov. Vet. Res., v.45, p.73-78, 2008.

JIN, X.; WANG, H.; WANG, S. et al. Serologic survey for antibodies to parvovirus in canines and felines. Acta Theriol. Sin., v.32, p.78-82, 2012.

KALLI, I.; LEONTIDES, L.S.; MYLONAKIS, M.E. et al. Factors affecting the occurrence, duration of hospitalization and final outcome in canine parvovirus infection. Res. Vet. Sci., v.89, p.174-178, 2010.

LAMM, C.G.; REZABEK, G.B. Parvovirus infection in domestic companion animals. Vet. Clin. N. Am. Small Anim. Pract., v.38, p.837-850, 2008.

LING, M.; NORRIS, J.M.; KELMAN, M. et al. Risk factors for death from canine parvoviralrelated disease in Australia. Vet. Microbiol., v.158, p.280-290, 2012.

MACARTNEY, L.; MCCANDLISH, I.A.; THOMPSON, H. et al. Canine parvovirus enteritis 1: clinical, haematological and pathological features of experimental infection. Vet. Rec., v.115, p.201-210, 1984.

MEUNIER, P.; COOPER, B.; APPEL, M. et al. Pathogenesis of canine parvovirus enteritis: the importance of viremia. Vet. Pathol., v.22, p.617624, 1985. 
MYLONAKIS, M.E.; KALLI, I.; RALLIS, T.S. Canine parvoviral enteritis: an update on the clinical diagnosis, treatment, and prevention. Vet. Med. Res. Rec., v.7, p.91-100, 2016.

NTAFIS, V.; XYLOURI, E.; KALLI, I. et al. Characterization of canine parvovirus 2 variants circulating in Greece. J. Vet. Diagn. Invest., v.22, p.737-740, 2010.

OLIVEIRA， P.S.B.; CARGNELUTTI， J.F.; MASUDA, E.K. et al. New variants of canine parvovirus in dogs in southern Brazil. Arch.Virol., v.164, p.1361-1369, 2019.

PARRISH, C.R. Pathogenesis of feline panleukopenia virus and canine parvovirus. Bailliere's Clin. Haematol., v.8, p.57-71, 1995.

PINTOS, A.B.; LARRAMA, C.B.N.; BARATTA, E.E.R. et al. Isolamento e caracterização da cepa tipo 2c do parvovirus canino circulante no Uruguai. Cienc.Rural, v.41, p.1436-1440, 2011.

PRITTIE, J. Canine parvoviral enteritis: a review os diagnosis, management, and prevention. J. Vet. Emerg. Crit. Care, v.14, p.167-179, 2004.

ROLIM, V.M.; SONNE, L.; CASAGRANDE, R.A. et al. Enteritis caused by type 2c canine parvovirus in a 5-year-old dog. Acta Sci. Vet., v.42, p.1-4, 2014.

ROSENFELD, S.J.; YOUNG, N.S. Viruses and bone marrow failure. Blood Rev., v.5, p.71-77, 1991.

SCHOEMAN, J.; GODDARD, A.; LEISEWITZ, A. Biomarkers in canine parvovirus enteritis. $N$. Engl. J. Med., v.1, p.1-6, 2013.
SCHUNCK, B.; TRUYEN, U. Case report: effect of maternal antibodies on the vaccination against canine parvovirus. Tierärztl. Praxis, v.23, p.185186, 1995.

SIEDEK, E.M.; SCHMIDT, H.; STURE, G.H. et al. Vakzinierung mit caninem Parvovirus Typ 2 (CPV-2) schützt gegen eine Belastungsinfektion mit virulenten CPV-2b und CPV-2c. Berl. Munch. Tierarztl Wochenschr, v.124, p.58-64, 2011.

SMITH-CARR, S.; MACINTIRE, D.; SWANGO, L. Canine parvovirus: part 1. pathogenesis and vaccination. Comp. Contin. Educ. Pract. Vet., v.19, p.125-133, 1997.

STOCKHAM, S.; SCOTT, M. Leukocytes. In: (Eds.). Fundamentals of veterinary clinical pathology. 2.ed. Iowa: Blackwell Publisher, 2008. p.53-106.

TRUYEN, U.; HORZINEK, M.C. Vaccination management in the dog: core components. Kleintierpraxis, v.52, p.162, 2007.

VAN HEERDEN, J.; BINGHAM, J.; VAN VUUREN, M. et al. Clinical and serological response of wild dogs (Lycaon pictus) to vaccination against canine distemper, canine parvovirus infection and rabies. J. South Afr. Vet. Assoc., v.73, p.8-12, 2002.

WEISER, G. Veterinary hematology and clinical chemistry. 2.ed. Oxford: Wiley Blackwell, 2012. $784 \mathrm{p}$.

WILSON, J.H.G.; HERMANN-DEKKERS, W.M. Experiments with a homologous, inactivated canine parvovirus vaccine in vaccination programmers for dogs. Vet. Q., v.4, p.108-116, 1982. 